\title{
Growth Analysis of Okra Production in Balod District of Chhattisgarh
}

\author{
Yogeshwari Sahu*, A. K. Sarawgi and Neha Dwivedi \\ Department of Agricultural Economics and Farm Management, College of Agriculture, \\ JNKVV, Jabalpur, India \\ *Corresponding author
}

Keywords

Chhattisgarh,

Trend, Growth, Okra

Article Info

\section{Accepted:}

12 January 2021

Available Online:

10 February 2021
The present study was carried out to determine the trend and growth of okra production in Balod District of Chhattisgarh. The secondary data was collected for the period from 2005-06 to 2015-16. The statistical tools like linear equation were used to know the trend and growth rate of area, total production and productivity of okra. Trend coefficient for area, total production and productivity of okra was estimated positive and highly significant at 1 percent level in Balod district which shows that the area, total production and productivity of okra in Balod district shows increases during study period. The regression coefficient for area and total production of okra was found positive and significant at 1 percent level also positive and 10 percent level of significance for productivity of okra in Chhattisgarh.

\section{Introduction}

Indian economy is mainly based on Agriculture, the annual output from the agricultural sector is an important factor in the growth of the economy. India is the second largest producer of vegetables in the world and more than 40 kinds of vegetables from different groups are grown in India. Tomato, onion, brinjal, cabbage, cauliflower, okra and pea are among the most important vegetables grown in India. In India the area under Horticultural crops which was 23.69 million hectares during 2012-13 and it increased to 24.92 million hectares during 2016-17. The total Horticultural production was 295.16 million tonnes as compared to 273.38 million tonnes of food grain production during 201617 (Horticultural Statistics at a Glance, 2016 $\&$ 2017).

Diversification towards Horticultural crops has been suggested as a viable option to stabilize and raise farm income, enhance agril. growth and increase employment opportunities in the agril. sector (Indian 
Horticulture Database-2014). The Horticulture has emerged as in indispensible part of agriculture, offering ample opportunities for sustaining large number of agro-based industries which generate substantial employment opportunities and play a vital role in providing livelihood security to the farmers.

Over the last decade, the area under Horticulture grew by about 3 percent per annum and annual production increased by 5.4 percent during 2016-17, the production of Horticulture crops was about 295.2 million tonnes from an area of 24.9 million hectares (Horticultural Statistics at a Glance, 2017).

India stands first in Okra production in world, contributing 70.90 percent share of total world production (2012-13).

The major Okra producing states are Andhra Pradesh, West Bengal, Bihar, Orrisa, Gujarat and Chhattisgarh. The estimated area of Okra crop in Chhattisgarh was 30134 hectares and 340198 metric tonne production (2015-16).

Okra (Abelmoschus esculentus L) is one of the principal horticultural crops in Chhattisgarh. There has been consistent in area under okra due to extension of its cultivation to entire parts of the state. In Chhattisgarh State, there is remarkable gap between actual harvested yield and potential yield of vegetable crops. In the State, during 2010-11 vegetables occupied an area of 0.346 million hectares with the production 4.25 million metric tonnes, which accounted 4.1 and 2.9 percent over the national figures, respectively.

The productivity of State 12.3 metric tonnes is quite less than the national average i.e. 17.3 metric tonnes. Vegetables are produced more or less in all the districts of the State, most prominent areas are of tomato $(12.81 \%)$, potato $(10.87 \%)$, brinjal $(7.97 \%)$, okra (7.53\%), cauliflower (5.49\%), cabbage
(4.39\%), cowpea (3.68\%) and onion (3.34\%). Production wise these crops follow same sequence of position in the State and the State has to go long way in vegetable production. Importance of vegetable is now much recognized and understood by agricultural community due to its wide range of utility and it has been observed that economic returns to vegetables are better than other several crops. The yield per unit area is high and suitable for intensive farming lead generation of supplement incomes and expands employment through it.

Vegetables support many other industries like processing, seed industry, fertilizer, pesticide and farm machinery industry. Vegetables support export and international trade.

Vegetables are always been a better choice of crop diversification because of good productivity and much higher returns from a unit area.

The diversification in favour of these crops improves exports, reduce trade deficit, besides creating more direct and indirect employment. Therefore, looking to the importance of vegetables has been undertaken to see the trend and variability.

\section{Materials and Methods}

The present study was carried out in the state of Chhattisgarh. Balod district of Chhattisgarh is selected purposively for the study as this district has 821 hectare of Okra area (201516). Balod district consists of five blocks namely: Balod, Gurur, Gunderdehi, Doundi and Doundi-Lohara, out of which one block i.e. Balod with highest area under okra was selected. The data used for the study is entirely secondary in nature and collected from C.G. Agril. Statistics and district Statistics. The secondary data was collected for the period from 2005-06 to 2015-16. 


\section{Analysis of data}

In order to fulfill the objectives of the study, the collected data were analyzed by using appropriate techniques and tools like linear equation.

\section{Method of analysis}

For estimation of trend and simple growth rate, following equation were used

$\mathrm{Y}=\mathrm{a}+\mathrm{b}_{1} \mathrm{x}_{1}$

Where,

$\mathrm{Y}=$ Dependent variable (i.e. Area, Total Production and Yield)

$\mathrm{a}=$ Constant $/$ Intercept

$b_{1}=$ Reg. coefficient or trend value

$\mathrm{x}_{1}=$ Independent variable (i.e. Years)

\section{Simple Growth Rate}

$\mathrm{SGR}=b / \overline{\mathrm{y}} \times 100$

Where,

$\mathrm{b}=$ Reg. coefficient

$\bar{Y}=\sum Y / n$

\section{Results and Discussion}

Trends for area, total production and productivity of Okra in Balod district and Chhattisgarh

Linear equation was used for estimation of trend \& simple growth rates and details are given in Table 1 and 2 . It revealed from the Table 1 that the trend coefficient for area, total production and productivity of okra were observed positive and highly significant at 1 percent level in Balod district.

Thus it could be concluded that the area, total production and productivity of okra in Balod district shows increases during study period.

It revealed from the Table 2 that the regression coefficient for area and total production of okra was found positive and significant at 1 percent while in productivity of okra, it was positive and 10 percent level of significance.

Thus it could be concluded that the increasing trend of area, total production and productivity was observed under okra in Chhattisgarh.

It could be concluded that regression coefficient of area, total production and productivity of okra crop in Balod district were found positive and significant at 1 percent level of probability which shows okra crop gained significantly with respect to area, total production and productivity.

Trend and growth rate of area, total production and productivity of okra crop in Chhattisgarh also found positive and highly significant in the entire variable except productivity.

In productivity, the value of regression coefficient was also found positive but significant at 10 percent level.

It's indicates that there was clear cut effect of improved technology in Balod district as well as Chhattisgarh state. Efforts are required to improved more productivity of okra crop in the study area (Fig. 1-4). 
Table.1 Trend and SGR in area, total production and productivity of Okra in Balod district

\begin{tabular}{|c|c|c|c|}
\hline Particular & Constant (a) & Reg. Coefficient (b) & SGR (\%) \\
\hline $\begin{array}{c}\text { Area } \\
\text { (Ha) }\end{array}$ & 239.72 & $\begin{array}{c}53.48^{* * *} \\
(3.59)\end{array}$ & 9.54 \\
\hline $\begin{array}{c}\text { Total Production } \\
\text { (Mt) }\end{array}$ & 1249.96 & $\begin{array}{c}378.78^{*} * * \\
(20.65)\end{array}$ & 10.76 \\
\hline $\begin{array}{c}\text { Productivity } \\
\text { (Mt/ha) }\end{array}$ & 5.754 & $\begin{array}{c}0.076^{* * *} \\
(0.02)\end{array}$ & 1.23 \\
\hline
\end{tabular}

Figure in bracket shows the SE of concerned Reg. Coefficient. *** shows 1 percent level of significance.

Table.2 Trend and SGR in area, total production and productivity of Okra in Chhattisgarh

\begin{tabular}{|c|c|c|c|}
\hline Particular & Constant (a) & Reg. Coefficient (b) & SGR (\%) \\
\hline $\begin{array}{c}\text { Area } \\
\text { (Ha) }\end{array}$ & 18668.02 & $\begin{array}{c}1033.79 * * * \\
(71.62)\end{array}$ & 4.16 \\
\hline $\begin{array}{c}\text { Total Production } \\
\text { (Mt) }\end{array}$ & 136046.56 & $\begin{array}{c}20450.76^{* * *} \\
(4031.03)\end{array}$ & 7.91 \\
\hline $\begin{array}{c}\text { Productivity } \\
\text { (Mt/ha) }\end{array}$ & 7.976 & $\begin{array}{c}0.381^{*} \\
(0.16)\end{array}$ & 3.79 \\
\hline
\end{tabular}

Figure in bracket shows the SE of concerned Reg. Coefficient.

*** \&* shows 1 and 10 percent level of significance respectively.

Fig.1 Trends for area and total production of Okra in Balod district

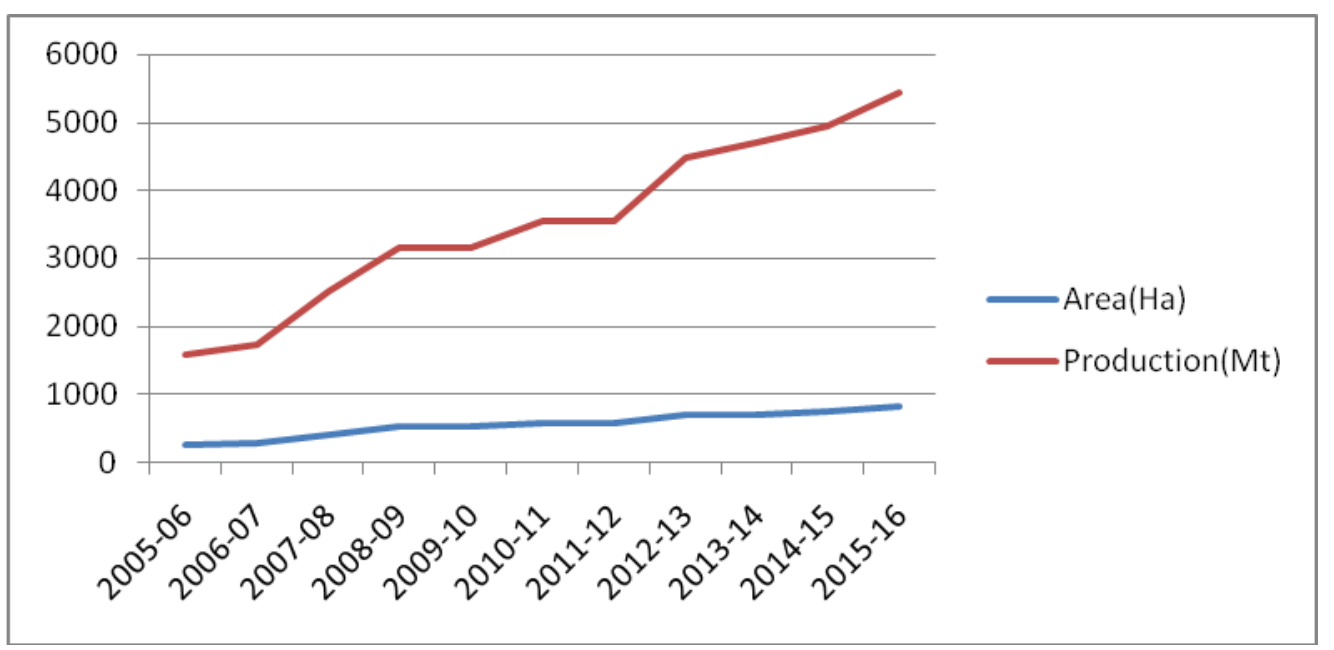


Fig.2 Trend for productivity of Okra in Balod district

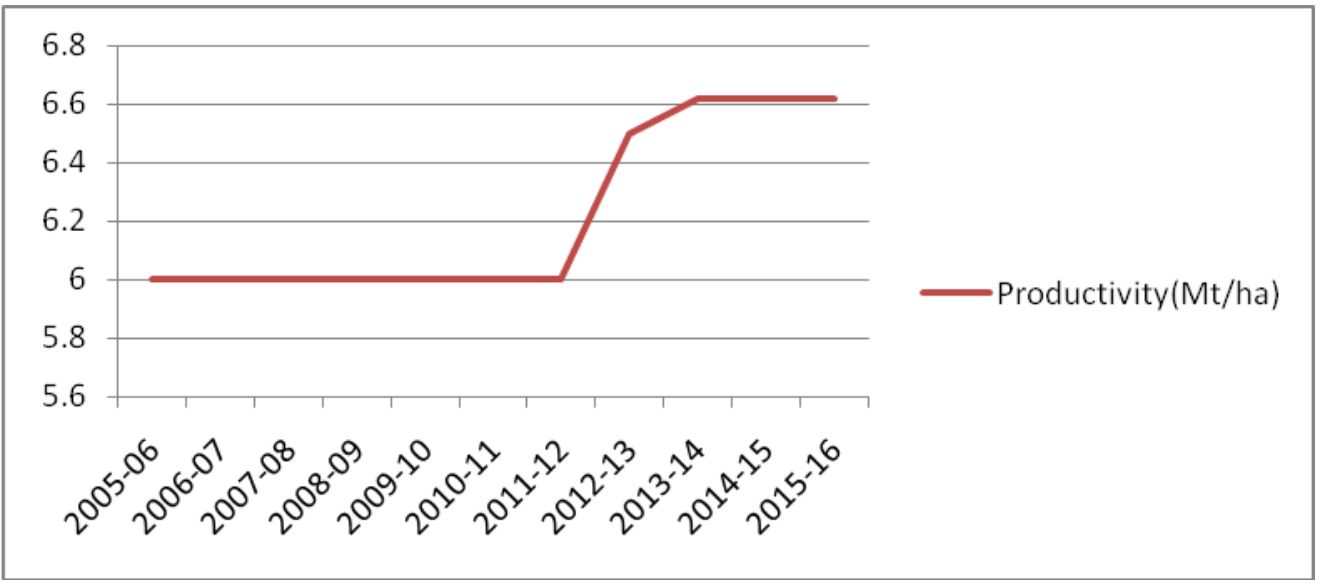

Fig.3 Trend for area and total production of Okra in Chhattisgarh

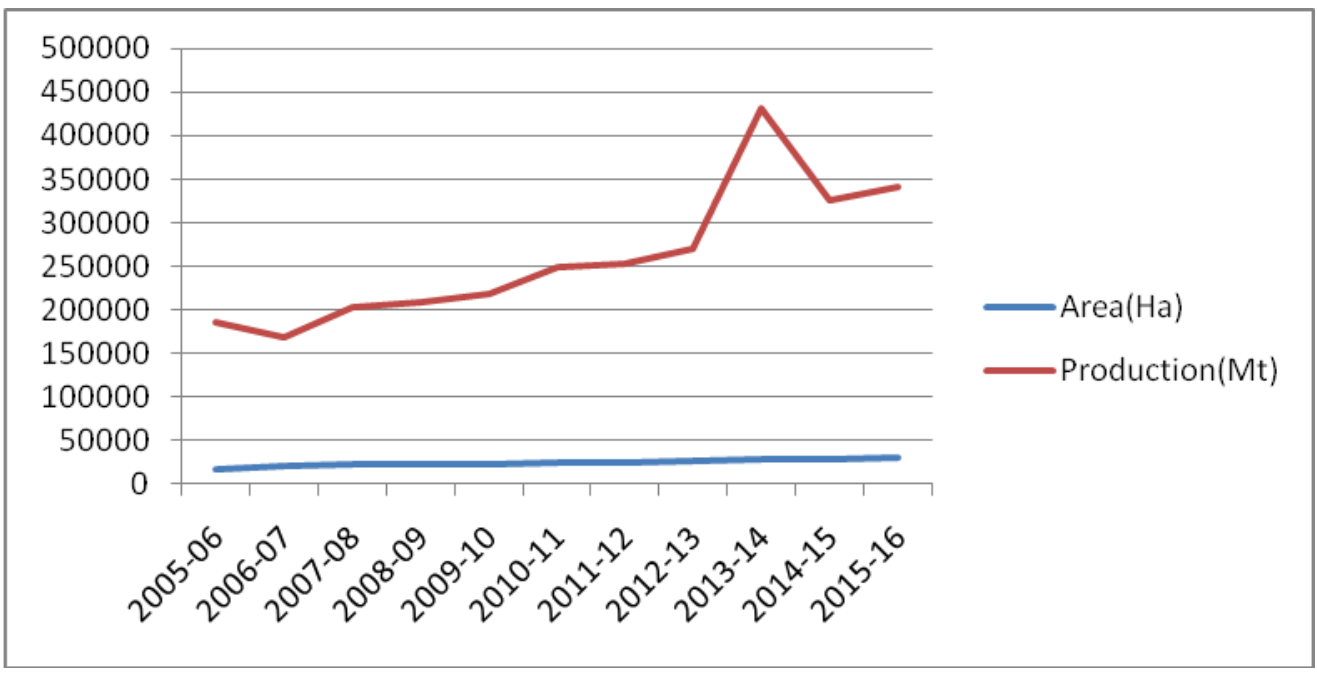

Fig.4 Trend for productivity of Okra in Chhattisgarh

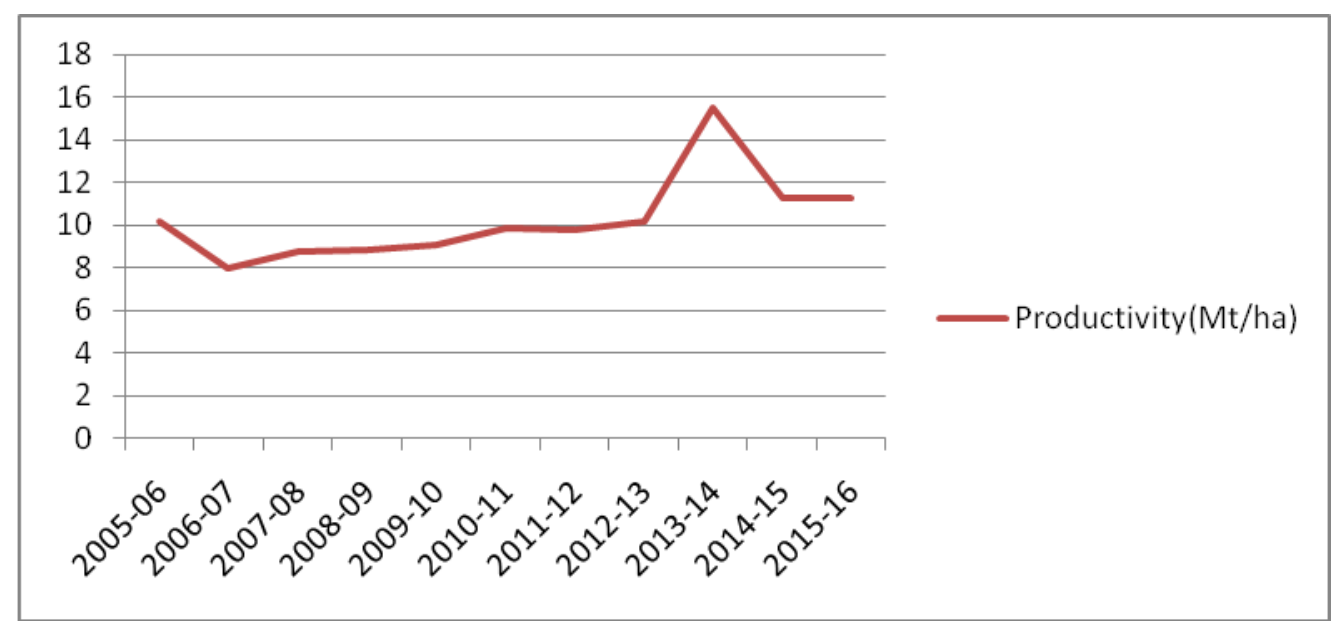




\section{References}

Horticultural Statistics at a Glance. (2017). Horticulture Statistics Division Department of Agriculture, Cooperation \& Farmers Welfare Ministry of Agriculture \& Farmers Welfare, Government of India.

Indian Horticulture Database. (2014). National Horticulture Board, Ministry of Agriculture, Government of India.

Godambe RB. 2013. Economics of production and disposal of okra in Thane district of Maharashtra. Agriculture Economic Research Review 26(9): 299-301.

Kumar N, Singh SP, Sharma M and Sharma PK. 2015. An Economic Analysis of Okra Cultivation in Jammu district of $\mathbf{J}$ \& $\mathrm{K}$ State, India. Division of Agricultural Economics and Statistics 21(1): 297-299.

Lokapur S and Kulkarni GN. 2014. Economics production of vegetables in Belgaum district in Karnataka. International Research Journal of Agricultural Economics and Statistics 5(2): 139-142.

Maurya OP and Pal SL. 2012. Economics of production and marketing of okra in district Bijnor (Uttar Pradesh).
Hortflora Research Spectrum 1(3):274277.

Ngbede SO, Onyegbule UN, Ibekwe HN, Uwalaka OA, Okpara SC. 2014. Economic Anaylsis of Okra Production under Different Rates of Organic Manure in Okigwe, Southern Nigeria. Asian Journal of Agriculture and Food Science 2(2): 96-99.

Sharma H, Parihar TB and Kapadia K. 2017. Growth Rates and Decomposition Analysis of Onion Production in Rajasthan State of India. Economic Affairs 62(1): 157-161.

Sharma P and Kaushal A. 2015. Economics of Growing Okra under Drip Fertigation. Indian Journal of Science and Technology 8(35): 1-5.

Singh RP and Toppo A. 2010. "Economics of Production and Marketing of Tomato in Kanke Block of Ranchi District". Indian Journal of Agricultural Marketing 24: 1-16.

Tegar A, Banafar KNS, Gauraha AK and Chandrakar MR. 2016. An Analysis Of Growth In Area, Production And Productivity Of Major Vegetables In Bilaspur District Of Chhattisgarh. Plant Archives 16(2): 797-800.

\section{How to cite this article:}

Yogeshwari Sahu, A. K. Sarawgi and Neha Dwivedi. 2021. Growth Analysis of Okra Production in Balod District of Chhattisgarh. Int.J.Curr.Microbiol.App.Sci. 10(02): 1583-1588. doi: https://doi.org/10.20546/ijcmas.2021.1002.188 